\title{
DESCRIPTION OF A NEW BAT-ASSOCIATED BUG SPECIES OF THE CIMEX LECTULARIUS GROUP FROM VIETNAM
}

\author{
Sándor HORNOK ${ }^{1 *}$, Dávid MURÁNYI ${ }^{2}$, Jenő KONTSCHÁN ${ }^{2}$ and Vuong TAN TU ${ }^{3,4}$ \\ ${ }^{1}$ Department of Parasitology and Zoology, University of Veterinary Medicine, István u. 2, \\ H-1078 Budapest, Hungary; ${ }^{2}$ Plant Protection Institute, Centre for Agricultural Research, \\ Hungarian Academy of Sciences, Budapest, Hungary; ${ }^{3}$ Institute of Ecology and \\ Biological Resources, Vietnam Academy of Science and Technology, Hanoi, Vietnam; \\ ${ }^{4}$ Graduate University of Science and Technology, Vietnam Academy of Science and \\ Technology, Hanoi, Vietnam
}

(Received 3 August 2018; accepted 20 November 2018)

Cimex lectularius, the common bedbug is an important, emerging pest of both veterinary and medical importance. Here a recently discovered, genetically distinct new species of the C. lectularius group is described morphologically, as Cimex pulveratus Hornok sp. nov.

Key words: Cimex, bedbug, Chiroptera, Hypsugo pulveratus, Vietnam

The common bedbug, Cimex lectularius Linnaeus, 1758 is a cosmopolitan blood-sucking ectoparasite, primarily infesting humans, but also frequently found on or near chickens and vespertilionid bats (Usinger, 1966). Bat-associated bugs of the Cimex lectularius group are not only important as pests, but also significant in an evolutionary context (Balvín et al., 2012a). Recently, two highly divergent novel genotypes have been reported in this species complex (Hornok et al., 2017). The purpose of the present study was to morphologically describe and illustrate that novel Cimex genotype which was the most different from other members of the C. lectularius group. In particular, the degree of barcoding sequence similarity between this novel genotype and C. lectularius was lower than between well-established Cimex species (Hornok et al., 2017), justifying the status of this novel genotype as a new species.

*Corresponding author; E-mail: hornok.sandor@univet.hu; Phone: 0036 (1) 478-4187

Open Access. This is an open-access article distributed under the terms of the Creative Commons AttributionNonCommercial 4.0 International License (https://creativecommons.org/licenses/by-nc/4.0/), which permits unrestricted use, distribution, and reproduction in any medium for non-commercial purposes, provided the original author and source are credited, a link to the CC License is provided, and changes - if any - are indicated. 


\section{Materials and methods}

Two bugs were collected from a male and a female Chinese pipistrelle (Hypsugo pulveratus Peters, 1870) at Ngoc Khe, Ngoc Lac, Thanh Hoa in Vietnam, 2011. DNA was extracted and two genetic markers were amplified, sequenced from the whole body of one male and from four legs of a female specimen, as reported (Hornok et al., 2017). Pictures were taken and measurements were performed with a VHX-5000 digital microscope (Keyence Co., Osaka, Japan). Sizes below are provided in $\mathrm{mm}$.

Cimex pulveratus Hornok sp. nov.

Taxonomic summary. Phylum Arthropoda, class Insecta, order Hemiptera, family Cimicidae, genus Cimex.

Diagnosis. Small-sized $(3.8 \mathrm{~mm})$ bug species with dense, short pubescence. Head and body brown, hemelytral pads golden yellow. Area around the paragenital sinus with bristles. Head broad, 2nd to 4th antennal segments long. Pronotum width to length ratio above 2.5 and hind margins of the hemelytral pads broadly rounded on inner halves (lectularius group). Paragenital sinus broadly rounded. Bristles anteriorly (on the pronotum and hemelytral pads), as well as posteriorly (last abdominal segment) exceed $100 \mu \mathrm{m}$.

\section{Type material and locality}

Holotype: female, collected at Hang Oc cave, Ngoc Khe, Ngoc Lac Secondary Forest after logging, surrounded by cultivated land (province: Thanh Hoa, geographic coordinates: N20.04,1860' - E105.23,2904', altitude: $37 \mathrm{~m}$ ) in Vietnam, from the bat species Hypsugo pulveratus. The holotype is deposited at the Institute of Ecology and Biological Resources, Vietnam Academy of Science and Technology, Hanoi, Vietnam (code: VN11-0422).

\section{Description}

Female. Head brown, considerably broader $(0.77$, including eyes) than long (0.45). Interocular space 0.55 , eyes 0.1 . Antennae 1.51 long, segments I-IV $0.16,0.43,0.55,0.37$. Second antennal segment shorter than interocular space. Ratio of head width to 2 nd and 3rd antennal segments 1.77 and 1.27 , respectively (Fig. 1a). Rostrum ventrally reaching coxae I, segments I-III 0.23, 0.16, 0.23 (Fig. 1b).

Pronotum brown, 1.16 wide, 0.4 long, width to length ratio 2.9. (Fig. 1a). Lateral margins rounded, with bristles up to 0.14 (anteriorly).

Hemelytral pads golden yellow, 0.9 wide, 0.55 long, broadly rounded on inner halves, at its sides long bristles up to 0.14 (Fig. 1a). Scutellum triangular, with short $(0.03)$ bristles in its posterior half, posterior edge close to midline 
slightly concave. Abdomen dorsally brown, ventrally segments golden yellowish posteriorly and towards midline, bristles usually below 0.1 . Paragenital sinus on 5 th abdominal segment broadly rounded, with bristles (Figs $1 \mathrm{~b}, \mathrm{~d}$ and e). Ectospermalege transverse, as shown in Figs $1 \mathrm{~b}$ and $\mathrm{d}$.
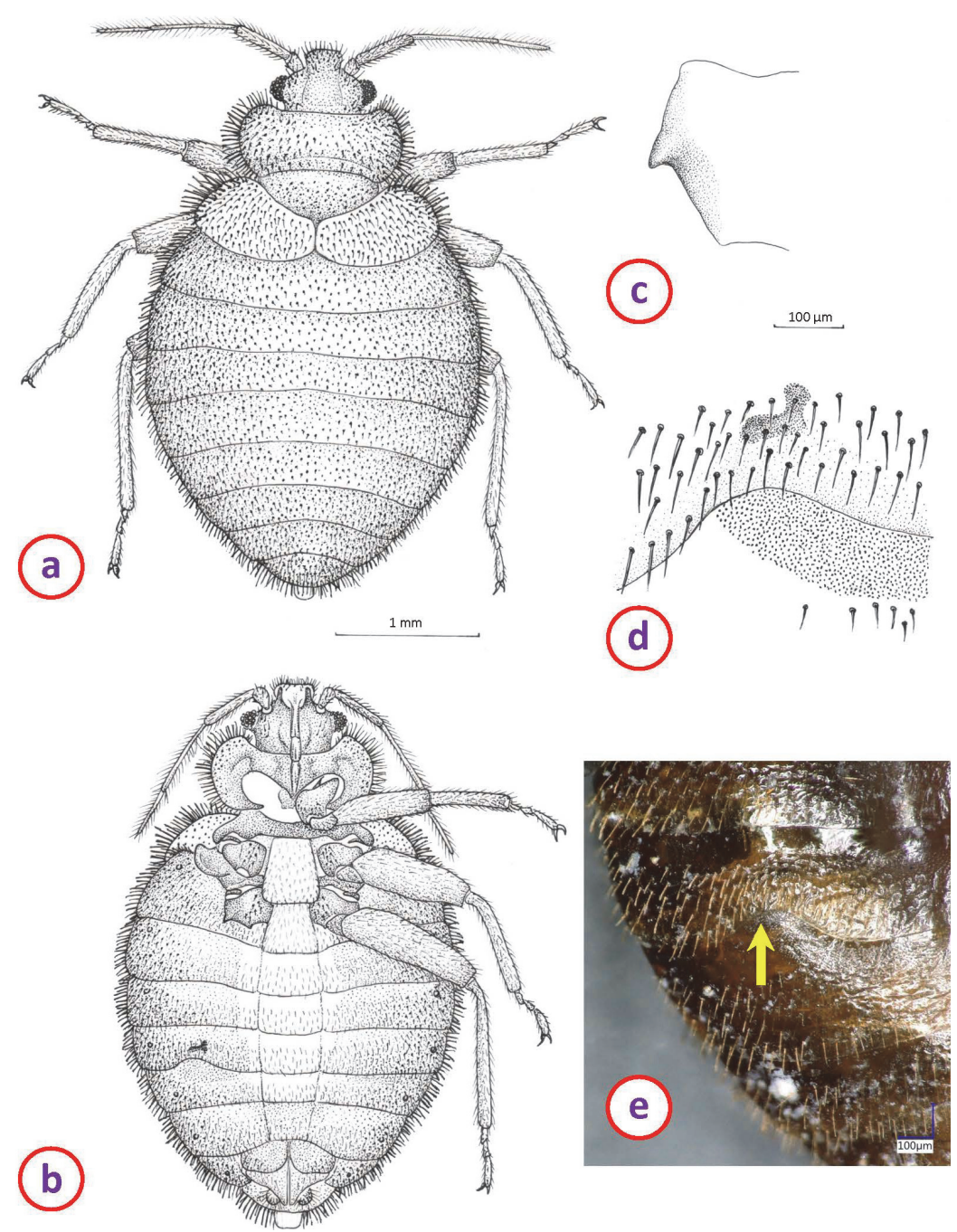

Fig. 1. Morphology of Cimex pulveratus sp. nov. female: (a) drawing of habitus: dorsal view; (b) drawing of habitus: ventral view; (c) drawing of spur on coxa III; (d) drawing of paragenital sinus; (e) picture of paragenital sinus (arrow)

Legs slender, except femur. Length of segments (3rd leg) from femur to tarsus: 1, 1, 0.1, 0.1, 0.2. Coxae trapezoid (Fig. 1b), coxa III with pointed, broadbased medial spur (Fig. 1c). 


\section{Gene sequences}

Mitochondrial cytochrome oxidase subunit I ( $\operatorname{cox} 1)$ gene sequence deposited in the GenBank is MF415647. The internal transcribed spacer 2 (ITS2) sequence is MF161540. The phylogenetic relationships of the new species have been reported (Hornok et al., 2017).

\section{Differential diagnosis}

Bristles around the paragenital sinus and width to length ratio of the pronotum distinguish the new species from members of the $C$. pipistrelli group.

Cimex lectularius group: concerning the morphology of females, C. pulveratus sp. nov. is similar to $C$. lectularius based on its coxal spur and width to length ratio of pronotum (exceeding 2.5). However, the paragenital sinus of $C$. pulveratus sp. nov. is different from that in C. lectularius and other Palearctic members of its group, i.e. it is rounded, which is a character of Neotropical species of the genus Cimex, not reported previously from the Old World (Usinger, 1966).

Cimex hemipterus group: $C$. pulveratus sp. nov. is similar to $C$. hemipterus Fabricius, 1803 based on its head shape (wider than long). In addition, the 2nd antennal segment is shorter than the interocular space. However, the width to length ratio of the pronotum of $C$. pulveratus sp. nov. exceeds 2.5 , unlike in the case of $C$. hemipterus. A further member of the $C$. hemipterus group, i.e. $C$. insuetus Ueshima, 1968 (indigenous in Thailand and India) can be distinguished from C. pulveratus sp. nov. by its width to length ratio of the pronotum (which is below 2), elongated head and 2nd antennal segment (which is longer than the interocular space) (Ueshima, 1968).

The above differences were confirmed by molecular and phylogenetic analyses (Hornok et al., 2017).

\section{Host records and distribution}

Known host species: Hypsugo pulveratus (of both bug specimens). Known distribution: Vietnam, Thanh Hoa, Ngoc Lac, Ngoc Khe.

\section{Etymology}

The new species was named after its host species, Hypsugo pulveratus.

\section{General}

In accordance with section 8.5 of the ICZN's International Code of Zoological Nomenclature, details of the new species have been submitted to ZooBank with the life science identifier (LSID) D64E4517-FF7C-48C4-9AAB60156E82517E. 


\section{Discussion}

In the family Cimicidae, the common bedbug (C. lectularius) can be regarded as the species with the highest historical, economical and veterinarymedical importance, also taking into account its worldwide occurrence and preference of human environment and body. Recently, high degrees of genetic differences have been reported between cimicid bugs, both within Europe and between specimens collected in Europe and Asia (Hornok et al., 2017). In particular, the sequence divergence between a newly discovered genotype (described here as $C$. pulveratus sp. nov.) and C. lectularius greatly exceed the limit of known intraspecific variation (Hornok et al., 2017), i.e. in the cox 1 gene this difference was above $17 \%$ in comparison with $C$. lectularius, while this value is $5.8-6.4 \%$ between $C$. lectularius and members of the $C$. hemipterus or $C$. pipistrelli species groups. In line with this, the morphological characteristics of $C$. pulveratus sp. nov. described above justify its distinct species status.

The host species of C. pulveratus sp. nov., i.e. Hypsugo pulveratus, is closely related to the genus Pipistrellus, which contains important hosts of batassociated bugs from both the lectularius and pipistrelli groups (Balvín et al., 2014). Host associations have been considered important drivers in the evolution/speciation of bat-associated bugs, as exemplified by C. lectularius (Balvín et al., 2012b; Booth et al., 2015). In the present case, to the best of our knowledge, no previous records and contemporaneous genetic/morphologic analyses of cimicid bugs from $H$. pulveratus are available. Thus, it can only be postulated that this host association may have contributed to the genetic and morphologic segregation of $C$. pulveratus sp. nov. Taking into account the geographic range of $H$. pulveratus (including China, Laos, Thailand and Vietnam), C. pulveratus sp. nov. most likely has a wide distribution in southeast Asia.

\section{Acknowledgements}

SH and VTT were supported by NKFIH 115854 and Rufford Foundation, respectively. Authorisation for bat capture was provided by the Vietnamese Ministry of Agriculture and Rural Development (Vietnam Administration of Forestry). The authors thank Alexandre Hassanin (Institute of Systematic Evolution and Biodiversity, Sorbonne University, Muséum National d'Histoire Naturelle, Paris, France) for providing the sample originally collected in Vietnam by Vuong Tan Tu. The publication of this research was supported by the 17896-4/2018/FEKUTSTRAT grant of the Hungarian Ministry of Human Capacities. 


\section{References}

Balvín, O., Munclinger, P., Kratochvíl, L. and Vilímová, J. (2012a): Mitochondrial DNA and morphology show independent evolutionary histories of bedbug Cimex lectularius (Heteroptera: Cimicidae) on bats and humans. Parasitol. Res. 111, 457-469.

Balvín, O., Ševčik, M., Jahelková, H., Bartonička, T., Orlova, M. and Vilímová, J. (2012b): Transport of bugs of the genus Cimex (Heteroptera: Cimicidae) by bats in western Palaearctic. Vespertilio 16, 43-54.

Balvín, O., Bartonička, T., Simov, N., Paunovic, M. and Vilímová, J. (2014): Distribution and host relations of species of the genus Cimex on bats in Europe. Folia Zool. 63, 281-289.

Booth, W., Balvín, O., Vargo, E. L., Vilimová, J. and Schal, C. (2015): Host association drives genetic divergence in the bed bug, Cimex lectularius. Mol. Ecol. 24, 980-992.

Hornok, S., Szőke, K., Boldogh, S. A., Sándor, A. D., Kontschán, J., Tu, V. T., Halajian, A., Takács, N., Görföl, T. and Estók, P. (2017): Phylogenetic analyses of bat-associated bugs (Hemiptera: Cimicidae: Cimicinae and Cacodminae) indicate two new species close to $\mathrm{Ci}$ mex lectularius. Parasit. Vectors 10, 439.

Ueshima, N. (1968): New species and records of Cimicidae with keys (Hemiptera). Pan-Pacific Entomologist 44, 264-279.

Usinger, R. L. (1966): Monograph of Cimicidae. Maryland: College Park. Entomol. Soc. America. p. 585. 